\title{
Kajian Kesiapan Penerapan Konsep Kota Kreatif Desain Di SURAKARTA
}

\author{
Amesta Kartika Ramadhani, Soedwiwahjono, Rufia Andisetyana Putri \\ Program Studi Perencanaan Wilayah dan Kota, \\ Jurusan Arsitektur, Fakultas Teknik \\ Universitas Sebelas Maret, Surakarta \\ email: amestaramadhani@gmail.com
}

\begin{abstract}
City plays important role making the city owns its high enchantment. This could effect on the emerging of city's problems, where the city could not accommodate to all the complexity of people interest. Those problems need a new strategy to solve city's problem which is more suitable to globalization era. The suitable solution is creative city which means city must be attractive by optimizing city's local potentials. Surakarta, since 2013 has been established by the Ministry Of Tourism and Creative Economy of Indonesia to be a creative city of design by UCCN (UNESCO Creative City Network). There is much potency supporting Surakarta to be city of design. The existence of creative industries such as batik and furniture, various creative communities, creative spaces (Benteng Vastenburg, ISI, batik training organizations), and also various events based on cultural are good aspect to be considered.

This research has purpose on knowing the readiness of Surakarta in implementing Creative City Of Design. The boundaries of this research are readiness of creative economy, readiness of creative community, readiness of creative space, readiness of leading, and readiness on holding events. This action then is followed by analyzing the readiness score of Surakarta as creative city of design. The research finding shows the readiness scales of Surakarta as creative city of design based on the five requirements that creative city must have. The research shows that Surakarta is not ready yet to be a creative city of design. There are some criterias that have not been accomplished. Creative economy, creative space, and experience in holding event are the lowest supporting aspect. Creative economy is the average in supporting creative city of design. Then the leading is the only one aspect who is ready in supporting implementation of Surakarta as city of design.
\end{abstract}

Keywords: creative city, city of design

\section{PENDAHULUAN}

Sebagai pusat kegiatan masyarakat, kota memiliki peran penting dan strategis, baik bagi kota itu sendiri maupun bagi kawasan perkotaan secara nasional. Peran tersebut menyebabkan kota memiliki daya tarik yang tinggi dan dapat berujung pada permasalahan kota. Beberapa permasalahan kota yang muncul antara lain adalah kemiskinan, kesenjangan sosial, dan kurangnya lapangan pekerjaan.

Permasalahan tersebut terus berkembang seiring dengan globalisasi, sehingga solusi penyelesaian masalah perkotaan seharusnya disesuaikan dengan era globalisasi. Solusi yang cukup tepat dalam mengatasi permasalahan kota adalah dengan perencanaan kota yang mampu mendorong kota lebih atraktif, dan mampu mengoptimalkan potensi dan mengubah permasalahan menjadi tantangan. Salah satu strategi baru perencanaan kota yang membuat kota lebih atraktif dengan mengutamakan lokalitas kota adalah dengan konsep kota kreatif (Landry, 2006).

Kota kreatif adalah kota yang di dalamnya terdapat individu-individu kreatif yang melakukan segala sesuatu dengan cara yang kreatif (Landry, 1998). Kota kreatif telah diterapkan di beberapa kota di dunia sejak kemunculannya. Kota-kota ini terhubung dalam jaringan kota kreatif UNESCO yang bertujuan untuk mengembangkan kerjasama internasional. kotaUNESCO juga mengelompokkan kota kreatif berdasarkan tema tertentu, yaitu kota sastra, sinema, musik, 
kerajinan dan kesenian rakyat, desain, seni media dan kuliner.

Surakarta sejak tahun 2013 telah ditunjuk oleh Kementerian Pariwisata dan Ekonomi Kreatif untuk diajukan sebagai kota kreatif desain versi UNESCO. Adanya orang-orang kreatif (komunitas kreatif) tampak pada beragamnya industri kreatif di Surakarta. Desain merupakan salah satu pencerminan kota Surakarta, khususnya desain tekstil dan fesyen (batik) yang sudah melegenda dan telah menjadi ciri khas kota Surakarta. Walaupun industri desain di Surakarta tidak hanya desain tekstil dan fesyen (termasuk juga desain produk), namun batik lah yang mampu menjadi ikon kota Surakarta. Selain dari sisi kemapanan industri batik, dari segi lingkungan kreatif Surakarta juga memiliki keterkaitan dengan desain, seperti adanya sekolah dan pusat industri desain seperti ISI, UNS, UMS, dan SMK. Dari aspek penyelenggaraan event (pameran/festival), Surakarta juga telah berpengalaman karena memiliki 47 event berbasis budaya setiap tahunnya. Beberapa event yang cukup terkenal dan didedikasikan utuk desain adalah Solo Batik Carnival dan Solo Batik Fesyen.

Secara garis besar, terdapat beberapa aspek yang mendukung penerapan konsep kota kreatif desain di Surakarta seperti industri kreatif, komunitas kreatif, lingkungan kreatif dan event. Berdasarkan isu yang sedang berkembang, penelitian ini ingin mengetahui bagaimana kesiapan kota Surakarta dalam penerapan konsep kota kreatif desain.

\section{METODE}

\subsection{Ruang Lingkup}

Ruang lingkup wilayah dalam penelitian ini adalah Kota Surakarta sebagai salah satu kota yang sedang didaftarkan dalam jaringan kota kreatif dunia dengan tema desain. Ruang lingkup substansi adalah kesiapan penerapan kota kreatif desain yang meliputi ekonomi kreatif, komunitas kreatif, lingkungan kreatif, kepemimpinan dan penyelenggaraan event.

\subsection{Metode Analisis}

Analisis dilakukan dengan dua tahapan yaitu analisis kesiapan tiap variabel dengan teknik analisis skoring (lihat Lampiran 1), kemudian hasil dari analisis tiap variabel menjadi input dari analisis kesiapan penerapan kota kreatif desain di Surakarta. Untuk menentukan skor hasil kesiapan, baik untuk masing-masing variabel maupun seluruh variabel, maka digunakan langkahlangkah sebagai berikut :

1. Menentukan rentang dari kelas interval yang dilakukan dengan pengurangan antara nilai maksimal dengan nilai minimal.

2. Menentukan banyak kelas interval yang dilakukan berdasarkan kategori skoring, sehingga terdapat 3 kelas interval.

3. Menentukan panjang kelas interval dengan pembagian antara rentang kelas dengan banyaknya kelas interval.

4. Menentukan kelas interval dengan menambahkan nilai ujung bawah dengan panjang kelas. Untuk ujung kelas interval berikutnya dilakukan dengan menambahkan ujung atas kelas sebelumnya dengan 1 .

5. Menghitung nilai kesiapan dengan menjumlahkan hasil, kemudian menyesuaikan nilai akhir kategori skoring.

\section{HASIL DAN PEMBAHASAN}

\subsection{Kesiapan Ekonomi Kreatif}

Kesiapan ekonomi kreatif dilihat dari beberapan aspek yaitu jumlah lapangan kerja, jumlah tenaga kerja, serta kemudahan pemanfaatan bahan baku lokal.

Nilai skoring kesiapan ekonomi kreatif berdasarkan lapangan kerja, tenaga kerja dan kemudahan pemanfaatan bahan baku lokal adalah lima (5) atau termasuk dalam kategori tidak siap dalam mendukung kota kreatif desain (lihat Lampiran 2).

Jumlah lapangan kerja sudah memenuhi kriteria, tetapi jumlah tenaga kerja industri kreatif subsektor masih belum mencukupi. Jumlah tenaga kerja berkaitan dengan tidak seimbangnya lapangan kerja dan tenaga kerja di industri kreatif subsektor desain. 
Jumlah lapangan kerja subsektor desain di Surakarta adalah 292. sementara di Montreal kota yang sudah ditetapkan sebagai kota kreatif desain UNESCO, lapangan pekerjaan di industri kreatif yang berkaitan dengan desain sejumlah 20.356 (UNESCO, 2007). Jumlah ini sangat banyak jika dibandingkan dengan Surakarta. Di Montreal, industri kreatif subsektor desain terdiri dari interior, grafik, fesyen, arsitektur dikembangkan bersama-sama). Untuk tenaga kerja, persentase jumlah tenaga kerja industri subsektor desain dengan industri pengolahan adalah 5,43\% sedangkan di Montreal, penyerapan tenaga kerja subsektor desain adalah $4 \%$ tetapi dari semua lapangan kerja, bukan hanya dibandingkan dengan industri.

\subsection{Kesiapan Kepemimpinan}

Kesiapan kepemimpinan dilihat dari kesiapan dua aspek yaitu kemitraan dan rencana pengembangan kota kreatif desain. Nilai skoring kesiapan kepemimpinan di Surakarta adalah lima (5) atau termasuk dalam kategori siap (lihat Lampiran 3). Walaupun sudah termasuk dalam kategori siap tetapi pelibatan masyarakat dalam kemitraan belum terjadi. Ketersediaan dukungan dalam bentuk pemangku kepentingan yang saling bekerja sama akan mengingkatkan kemampuan untuk berinovasi. Adanya pemangku kepentingan dengan latar belakang yang berbeda-beda juga bermanfaat dalam menghubungkan banyak orang yang berbeda-beda. Di Surakarta, kemampuan berinovasi masih belum lengkap karena dari aspek masyarakat belum terlibat secara langsung dalam pengembangan kota kreatif. Sebagian besar masyarakat hanya menjadi objek dari rencana pengembangan.

Pada rencana pengembangan termasuk dalam kategori siap, tetapi namun rencana pengembangan masih perlu satu aspek untuk dimasukkan dalam rencana pengembangan, yaitu aspek komunitas kreatif. Menurut Landry (2006) dalam rencana pengembangan kota kreatif harus mencakup empat elemen yaitu, ekonomi, lingkungan, komunitas dan wisata budaya. Di Surakarta, belum ada rencana mengenai komunitas kreatif karena masih dalam proses pemetaan

\subsection{Kesiapan Komunitas Kreatif}

Kesiapan komunitas kreatif dilihat dari nilai keragaman budaya, banyaknya masyarakat kreatif dan jumlah usia produktif. Nilai kesiapan komunitas kreatif di Surakarta adalah enam (6) atau termasuk dalam kategori agak siap (lihat Lampiran 4). Secara keseluruhan masyarakat kota Surakarta sudah memiliki elemen pendukung kota kreatif desain dari segi kesiapan komunitas kreatifnya, terutama potensi penduduk usia produktif yang tinggi, hanya saja masih perlu dikembangkan karena nilai keragamannya masih rendah. Untuk menjadi kota kreatif dibutuhkan masyarakat yang beragam sehingga dapat menghasilkan kreativitas yang beragam pula.

Saat ini di Surakarta, komunitas dengan jumlah terbanyak adalah komunitas yang hanya berdasarkan hobi semata seperti komunitas pecinta klub sepakbola, pecinta hewan, dll. Diperlukan jumlah komunitas kreatif pada industri kreatif yang selisihnya tidak terlalu tinggi dengan komunitas hobi sehingga dapat meningkatkan nilai keragaman bakat. Dari keragaman penduduk, proporsi jumlah penduduk pendatang dan penduduk asli hanya mencapai $0,3 \%$ atau dikatakan rendah. Proporsi jumlah penduduk pendatang rendah karena masih didominasi oleh penduduk asli Surakarta.

Tingkat partisipasi penduduk dalam penyelenggaraan event juga masih sebatas sebagai penonton. Adanya tingkat partisipasi yang lebih tinggi (sebagai penyelenggara), tingkat partisipasi akan naik jika masyarakat Surakarta ikut berperan aktif dalam penyelenggaraan event. Di Bandung misalnya, terdapat komunitas kreatif yang menggelar event rutin setiap seminggu sekali dalam mendukung wisata kampung kreatif. Hal ini akan meningkatkan kemampuan masyarakat dalam mendukung kesiapan komunitas kreatif. 


\subsection{Kesiapan Lingkungan Kreatif}

Nilai untuk kesiapan lingkungan kreatif adalah satu atau termasuk dalam kategori tidak siap (lihat Lampiran 5). Hal ini disebabkan karena jumlah infrastruktur lunak belum memenuhi kriteria kesiapan untuk aspek lingkungan kreatif. Untuk mencari nilai kesiapan lingkungan kreatif adalah dengan menggunakan nilai persilangan antara nilai infrastruktur keras dan infrastruktur lunak. Jumlah infrastruktur keras dan lunak yang terkait dengan desain masih sedikit sehingga berpengaruh pada nilai kesiapan lingkungan kreatif.

Infrastruktur lunak sebagian besar adalah milik pribadi sehingga pemerintah hanya bisa mendukung keberadaan infrastruktur lunak tersebut. Orang-orang yang mengakses infrastruktur lunak tidak sebanyak orang yang mengakses infrastruktur keras karena hanya orang-orang yang memiliki minat khusus yang menggunakan infrastruktur lunak. Biasanya orang-orang yang mau belajar membatik yang belajar di lembaga pelatihan batik. Agar nilai kesiapan lingkungan kreatif meningkat menjadi kategori siap, maka perlu penambahan jumlah infrastruktur lunak, seperti lembaga pelatihan dan kelompok peneltian yang memiliki unsur desain.

\subsection{Kesiapan Penyelenggaraan Event}

Nilai untuk kesiapan penyelenggaraan event adalah satu atau termasuk dalam kategori tidak siap (lihat Lampiran 6). Jumlah event yang didedikasikan untuk desain masih belum memenuhi kriteria kesiapan, walaupun skalanya sudah besar, tetap belum bisa mendukung kesiapan kota kreatif desain. Di Surakarta event terkait dengan desain belum mampu menarik wisatawan mancanegara dalam jumlah yang besar. Event-event yang terkait dengan desain juga masih belum banyak bervariasi, kebanyakan bertema batik dan masih sedikit dalam pelaksanaan event yang bertajuk dialog ataupun konferensi untuk mengembangkan prouk desain.

3.6 Analisis Kesiapan Penerapan Konsep Kota Kreatif Desain di Surakarta

Analisis skoring kesiapan penerapan kota kreatif desain di Surakarta menunjukkan bahwa Surakarta masih tergolong dalam kategori tidak siap (lihat Lampiran 7). Banyak aspek-aspek dalam variabel yang belum memenuhi kriteria skoring dengan kategori siap. Hanya terdapat satu aspek yang termasuk siap dalam mendukung Surakarta sebagai kota kreatif desain yaitu kepemimpinan.

\section{KESIMPULAN}

Berdasarkan hasil analisis, Surakarta termasuk dalam kategori tidak siap dalam penerapan konsep kota kreatif desain. Hal ini disebabkan karena masih banyak kriteria kesiapan yang belum tercukupi. Aspek ekonomi kreatif, lingkungan kreatif dan penyelenggaraan event merupakan aspekaspek yang memiliki kesiapan rendah atau tidak siap dalam penerapan kota kreatif desain sedangkan aspek komunitas kreatif termasuk dalam kategori agak siap karena adanya potensi jumlah penduduk usia muda dan kebanggaan masyarakat terhadap identitas lokal yang cukup tinggi. Aspek kepemimpinan merupakan satu-satunya aspek yang sudah siap dalam mendukung Surakarta sebagai kota kreatif desain.

\section{REFERENSI}

Landry, Charles, 2006, The Creative City: A Toolkit For Urban Innovator $\left(2^{\text {nd }}\right.$ edition), London, Earthscan.

Landry, Charles and Bianchini, Franco, 1998, The Creative City, London: Demos.

Creative City Network. 2007. Montreal Unesco City Of Design

Ramadhani, Amesta Kartika. 2015. Kajian Kesiapan Penerapan Konsep Kota Kreatif Desain di Surakarta, Tugas Akhir Program Sarjana Perencanaan Wilayah dan Kota UNS 
LAMPIRAN

Lampiran 1. Skoring Tiap Variabel

\begin{tabular}{|c|c|c|c|c|}
\hline \multirow[t]{2}{*}{ Variabel } & \multirow[t]{2}{*}{ Parameter } & \multicolumn{3}{|l|}{ Indikator } \\
\hline & & Siap (3) & Agak Siap (2) & Tidak Siap (1) \\
\hline \multirow[t]{3}{*}{ Ekonomi Kreatif } & $\begin{array}{lr}\text { Tercukupinya } & \text { jumlah } \\
\text { lapangan kerja di sektor } \\
\text { kreatif desain. }\end{array}$ & $\begin{array}{l}\text { - Jika lapangan kerja } \\
\text { industri kreatif desain } \\
\text { memiliki persentase 10- } \\
15 \% \text { atau lebih dari } \\
15 \%\end{array}$ & $\begin{array}{l}\text { - Jika lapangan kerja } \\
\text { industri kreatif desain } \\
\text { memiliki persentase } \\
5 \leq x<10 \%\end{array}$ & $\begin{array}{l}\text { Jika lapangan kerja } \\
\text { industri kreatif desain } \\
\text { memiliki persentase di } \\
\text { bawah 5\% }\end{array}$ \\
\hline & $\begin{array}{l}\text { Tercukupinya jumlah orang } \\
\text { yang bekerja di sektor } \\
\text { kreatif desain. }\end{array}$ & $\begin{array}{l}\text { - Jika persentase tenaga } \\
\text { kerja industri kreatif } \\
\text { desain } 40 \%-50 \% \text { atau } \\
\text { di atas } 50 \%\end{array}$ & $\begin{array}{ll}\text { - agak siap : Jika } \\
\text { persentase tenaga } \\
\text { kerja industri kreatif } \\
\text { desain di bawah } 40 \% \\
\text { dan di atas } 20 \% \\
(20 \% \leq x<40 \%)\end{array}$ & $\begin{array}{lll}\text { - Jika persentase } & \text { tenaga } \\
\text { kerja industri } & \text { kreatif } \\
\text { desain di bawah } 20 \%\end{array}$ \\
\hline & $\begin{array}{l}\text { ketersediaan dukungan } \\
\text { (kemudahan) } \\
\text { memanfaatkan bahan baku } \\
\text { lokal }\end{array}$ & $\begin{array}{l}\text { - Jika nilai persilangan } \\
\text { antara aksesibilitas dan } \\
\text { sumber bahan baku } \\
\text { lokal adalah } 8,36-12\end{array}$ & $\begin{array}{l}\text { - Jika nilai persilangan } \\
\text { antara aksesibilitas } \\
\text { dan sumber bahan } \\
\text { baku lokal adalah } \\
4,68-8,35\end{array}$ & $\begin{array}{l}\text { Jika nilai persilangan } \\
\text { antara aksesibilitas dan } \\
\text { sumber bahan baku lokal } \\
\text { adalah } 1-4,67\end{array}$ \\
\hline \multirow[t]{2}{*}{ Kepemimpinan } & $\begin{array}{l}\text { Tersedianya kemitraan } \\
\text { antarpemangku kepentingan } \\
\text { terkait pengembangan kota } \\
\text { kreatif }\end{array}$ & \begin{tabular}{lrr} 
Jika & terdapat & kemitraan \\
$3 \quad$ jenis & pemangku \\
kepentingan & yang \\
berperan & $(($ Public- \\
\multicolumn{2}{c}{ Private-Voluntary). }
\end{tabular} & $\begin{array}{l}\text { Jika hanya dua jenis } \\
\text { pemangku } \\
\text { kepentingan yang } \\
\text { berperan Public- } \\
\text { Private/Privat- } \\
\text { Voluntary/Public- } \\
\text { Voluntary) }\end{array}$ & $\begin{array}{lr}\text { Jika hanya } & \text { salah satu } \\
\text { jenis } & \text { pemangku } \\
\text { kepentingan } & \text { yang } \\
\text { berperan } & \\
\text { (public/privat/voluntary) }\end{array}$ \\
\hline & $\begin{array}{l}\text { Ketuntasan rencana } \\
\text { pengembangan kota kreatif }\end{array}$ & $\begin{array}{l}\text { - Nilai ketuntasan rencana } \\
\text { pengembangan kota } \\
\text { kreatif adalah } 81-120\end{array}$ & $\begin{array}{l}\text { - Nilai ketuntasan } \\
\text { rencana } \\
\text { pengembangan kota } \\
\text { kreatif adalah 41-80 }\end{array}$ & $\begin{array}{l}\text { Nilai ketuntasan rencana } \\
\text { pengembangan kota } \\
\text { kreatif adalah 0-40 }\end{array}$ \\
\hline \multirow[t]{3}{*}{$\begin{array}{l}\text { Komunitas } \\
\text { Kreatif }\end{array}$} & $\begin{array}{l}\text { Tercukupinya } \\
\text { keragaman }\end{array}$ & $\begin{array}{l}\text { Jika nilai persilangan } \\
\text { antara indeks shanon } \\
\text { dan proporsi pendatang } \\
6,36-9\end{array}$ & $\begin{array}{l}\text { Jika nilai persilangan } \\
\text { antara indeks shanon } \\
\text { dan proporsi } \\
\text { pendatang } 3,68-6,35\end{array}$ & $\begin{array}{l}\text { Jika nilai persilangan } \\
\text { antara indeks shanon dan } \\
\text { proporsi pendatang 1- } \\
3,67\end{array}$ \\
\hline & $\begin{array}{ll}\text { Tercukupinya jumlah } & \text { usia } \\
\text { produktif (dilihat } & \text { dari } \\
\text { piramida penduduk) } & \end{array}$ & 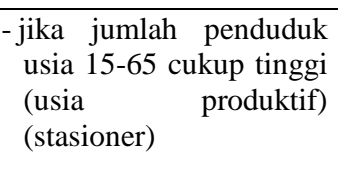 & $\begin{array}{l}\text { jika jumlah penduduk } \\
\text { usia di atas } 65 \text { tahun } \\
\text { berjumlah }>10 \% \text { dari } \\
\text { total penduduk } \\
\text { (konstruktif) }\end{array}$ & $\begin{array}{l}\text { - jika jumlah penduduk } \\
\text { usia di bawah } 15 \text { tahun } \\
\text { berjumlah }>40 \% \text { dari } \\
\text { total } \\
\text { (ekspansif) }\end{array}$ \\
\hline & $\begin{array}{lr}\text { Tercukupinya } & \text { nilai } \\
\text { kebanggaan } & \text { terhadap } \\
\text { Identitas lokal } & \end{array}$ & $\begin{array}{l}\text { Jika nilai persilangan } \\
\text { antara penggunaan } \\
\text { produk lokal dan } \\
\text { partisipasi terhadap } \\
\text { event adalah } 3,1-4 \\
\end{array}$ & $\begin{array}{l}\text { Jika nilai persilangan } \\
\text { antara penggunaan } \\
\text { produk lokal dan } \\
\text { partisipasi terhadap } \\
\text { event adalah } 2,1-3\end{array}$ & $\begin{array}{l}\text { Jika nilai persilangan } \\
\text { antara penggunaan } \\
\text { produk lokal dan } \\
\text { partisipasi terhadap } \\
\text { event adalah } 1-2 \\
\end{array}$ \\
\hline $\begin{array}{l}\text { Lingkungan } \\
\text { Kreatif }\end{array}$ & $\begin{array}{l}\text { Tersedianya ruang kreatif } \\
\text { yang mendukung proses } \\
\text { kreatif desain: } \\
\text { - infrastruktur keras yang } \\
\text { terdiri dari taman, } \\
\text { museum, galeri seni, } \\
\text { ruang pertunjukan } \\
\text { - infrastruktur lunak yang } \\
\text { terdiri dari lembaga } \\
\text { pelatihan, kelompok } \\
\text { penelitian }\end{array}$ & $\begin{array}{l}\text { jika lebih dari } 50 \% \\
\text { infrastruktur keras dan } \\
\text { lunak yang dimiliki } \\
\text { terkait desain }\end{array}$ & $\begin{array}{lr}\text { jika kurang } & \text { dari } 50 \% \\
\text { infrastruktur } & \text { keras } \\
\text { dan lunak yang } \\
\text { dimiliki terkait desain }\end{array}$ & $\begin{array}{l}\text { jika lebih dari } 50 \% \\
\text { infrastruktur keras dan } \\
\text { lunak yang dimiliki tidak } \\
\text { terkait desain }\end{array}$ \\
\hline $\begin{array}{l}\text { Penyelenggaraan } \\
\text { event }\end{array}$ & $\begin{array}{l}\text { Tersedianya event yang } \\
\text { berkaitan dengan creative } \\
\text { output (industri desain) }\end{array}$ & $\begin{array}{l}\text { Jika nilai persilangan } \\
\text { antara dedikasi event } \\
\text { dan skala event adalah } \\
3,1-4\end{array}$ & $\begin{array}{l}\text { Jika nilai persilangan } \\
\text { antara dedikasi event } \\
\text { dan skala event } \\
\text { adalah } 2,1-3\end{array}$ & $\begin{array}{l}\text { Jika nilai persilangan } \\
\text { antara dedikasi event dan } \\
\text { skala event adalah } 1-2\end{array}$ \\
\hline
\end{tabular}

Sumber : Ramadhani, 2015 
Lampiran 2. Hasil Skoring Kesiapan Ekonomi Kreatif

\begin{tabular}{|l|l|l|l|}
\hline \multirow{2}{*}{ Hasil } & \begin{tabular}{l} 
Indikator \\
\cline { 2 - 4 }
\end{tabular} & $\begin{array}{l}\text { Siap } \\
(3) \\
\text { Siap } \\
(2)\end{array}$ & $\begin{array}{l}\text { Tidak } \\
\text { Siap } \\
(1)\end{array}$ \\
\hline $\begin{array}{l}\text { Persentase kerja } \\
\text { lapangan } \\
\text { industri kreatif } \\
\text { subsektor desain } \\
\text { adalah 15,05\% }\end{array}$ & v & \\
\hline $\begin{array}{l}\text { Persentase tenaga } \\
\text { kerja industri } \\
\text { kreatif subsektor } \\
\text { desain sebesar } \\
\text { 5,43\% no }\end{array}$ & & \\
\hline $\begin{array}{l}\text { Aksesibilitas } \\
\text { cukup baik, bahan } \\
\text { baku dari luar } \\
\text { kota, nilai } \\
\text { persilangan } \\
\text { adalah empat }\end{array}$ & & & \\
\hline Nilai & & \\
\hline
\end{tabular}

Sumber : Ramadhani, 2015

Lampiran 3. Hasil Skoring Kesiapan Kepemimpinan

\begin{tabular}{|c|c|c|c|}
\hline \multirow[b]{2}{*}{ Hasil } & \multicolumn{3}{|c|}{ Indikator } \\
\hline & $\begin{array}{l}\text { Siap } \\
\text { (3) }\end{array}$ & $\begin{array}{l}\text { Agak } \\
\text { Siap } \\
\text { (2) }\end{array}$ & $\begin{array}{l}\text { Tidak } \\
\text { Siap } \\
\text { (1) }\end{array}$ \\
\hline $\begin{array}{lr}\begin{array}{l}\text { Kemitraan } \\
\text { dari }\end{array} & \text { terdiri } \\
\text { pemangku } & \\
\text { kepentingan } & \text { yaitu } \\
\text { pemerintah, } & \\
\text { swasta } & \text { dan } \\
\text { akademisi } & \\
\end{array}$ & & $\mathrm{v}$ & \\
\hline $\begin{array}{l}\text { Rencana } \\
\text { pengembangan } \\
\text { terdiri dari } \\
\text { rencana } \\
\text { lingkungan } \\
\text { kreatif, industri } \\
\text { kreatif dan } \\
\text { rencana wisata } \\
\text { budaya (nilai 90) }\end{array}$ & $\mathrm{v}$ & & \\
\hline Nilai & 5 & & \\
\hline
\end{tabular}

Sumber : Ramadhani, 2015
Lampiran 4. Hasil Skoring Kesiapan Komunitas Kreatif

\begin{tabular}{|c|c|c|c|}
\hline \multirow[b]{2}{*}{ Hasil } & \multicolumn{3}{|c|}{ Indikator } \\
\hline & $\begin{array}{l}\text { Siap } \\
\text { (3) }\end{array}$ & $\begin{array}{l}\text { Agak } \\
\text { Siap } \\
\text { (2) }\end{array}$ & $\begin{array}{l}\text { Tidak } \\
\text { Siap } \\
\text { (1) }\end{array}$ \\
\hline $\begin{array}{lr}\begin{array}{l}\text { Nilai } \\
\text { rendah }\end{array} & \text { keragaman } \\
\text { karena } & \text { nilai } \\
\text { indeks } & \text { shanon } \\
\mathrm{H}<1, & \text { jumlah } \\
\text { penduduk } & \\
\text { pendatang } & \text { rendah } \\
\text { hanya mencapai } \\
4,55 \% \text {. }\end{array}$ & & & $\mathrm{v}$ \\
\hline $\begin{array}{l}\text { Piramida } \\
\text { penduduk } \\
\text { stasioner (jumlah } \\
\text { penduduk pada } \\
\text { masing-masing } \\
\text { kelompok umur } \\
\text { hampir sama) }\end{array}$ & $\mathrm{v}$ & & \\
\hline $\begin{array}{l}74 \% \text { masyarakat } \\
\text { menggunakan } \\
\text { produk lokal dan } \\
66,7 \quad \% \\
\text { menghadiri event } \\
\text { lokal sehingga } \\
\text { nilai nilai } \\
\text { persilangan dua }\end{array}$ & & $\mathrm{V}$ & \\
\hline Nilai & 6 & & \\
\hline
\end{tabular}

Sumber : Ramadhani, 2015

Lampiran 5. Hasil Skoring Kesiapan Lingkungan Kreatif

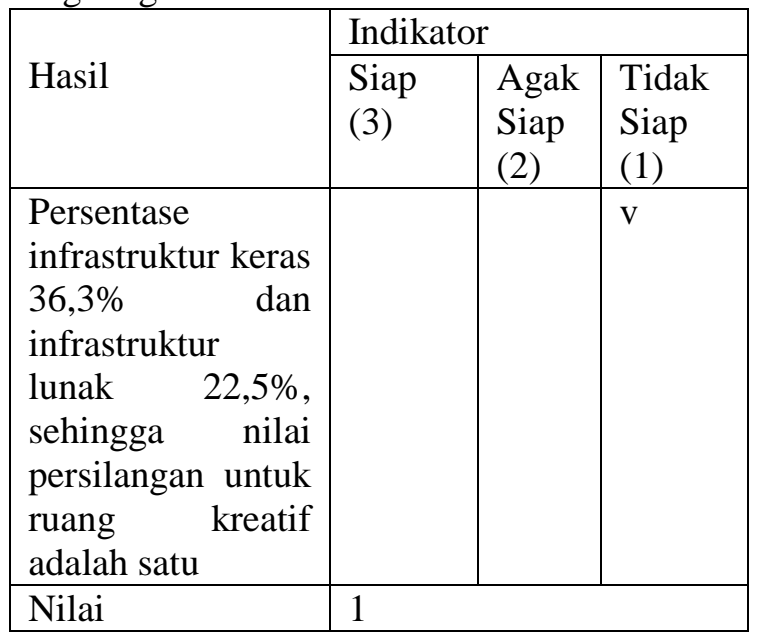

Sumber : Ramadhani, 2015 
Lampiran 6. Hasil Skoring Kesiapan Penyelenggaraan Event

\begin{tabular}{|c|c|c|c|}
\hline \multirow[b]{2}{*}{ Hasil } & \multicolumn{3}{|c|}{ Indikator } \\
\hline & $\begin{array}{l}\text { Siap } \\
\text { (3) }\end{array}$ & $\begin{array}{l}\text { Agak } \\
\text { Siap } \\
\text { (2) }\end{array}$ & $\begin{array}{l}\text { Tidak } \\
\text { Siap } \\
\text { (1) }\end{array}$ \\
\hline $\begin{array}{l}23,4 \% \text { event yang } \\
\text { dilaksanakan } \\
\text { terkait dengan } \\
\text { desain, dan } 45,4 \% \\
\text { memiliki skala } \\
\text { nasional atau } \\
\text { lebih besar, } \\
\text { sehingga nilai } \\
\text { persilangannya } \\
\text { adalah satu }\end{array}$ & & & $\mathrm{v}$ \\
\hline Nilai & 1 & & \\
\hline
\end{tabular}

Sumber : Ramadhani, 2015

Lampiran 7. Hasil Skoring Kesiapan Penerapan Konsep Kota Kreatif Desain di Surakarta

\begin{tabular}{|l|l|l|l|}
\hline \multirow{2}{*}{ Hasil } & \multicolumn{3}{|l|}{ Indikator } \\
\cline { 2 - 4 } & $\begin{array}{l}\text { Siap } \\
(3)\end{array}$ & $\begin{array}{l}\text { Agak } \\
\text { Siap } \\
(2)\end{array}$ & $\begin{array}{l}\text { Tidak } \\
\text { Siap } \\
(1)\end{array}$ \\
\hline Ekonomi kreatif & & & $\mathrm{v}$ \\
\hline Kepemimpinan & $\mathrm{v}$ & & \\
\hline Komunitas kreatif & & $\mathrm{v}$ & \\
\hline $\begin{array}{l}\text { Lingkungan } \\
\text { kreatif }\end{array}$ & & & $\mathrm{v}$ \\
\hline $\begin{array}{l}\text { Penyelenggaraan } \\
\text { event }\end{array}$ & & & $\mathrm{v}$ \\
\hline Nilai & 8 & & \\
\hline
\end{tabular}

Sumber : Ramadhani, 2015

DAFTAR PUSTAKA 